\title{
Short Communication: Relationship between interferon-tau level (IFN- $\tau$ ) and embryo mortality incident in Aceh cattle
}

\author{
JULI MELIA ${ }^{1}$, TONGKU NIZWAN SIREGAR ${ }^{1, \bullet}$, LUTHFY ALFAHMI ${ }^{1}$, HUSNURRIZAL $^{1}$, \\ HENDRA SAUMAR ${ }^{2}$, MUKHTAR ${ }^{2}$, NELLITA MEUTIA ${ }^{2}$, BUDIANTO PANJAITAN ${ }^{1}$, TEUKU ARMANSYAH ${ }^{1}$ \\ ${ }^{1}$ Faculty of Veterinary Medicine, Universitas Syiah Kuala. Jl Tgk. Hasan Krueng Kalee No. 4, Darussalam, Banda Aceh, 23111, Aceh, Indonesia. \\ Tel.: +62-651-7551536, `email: siregar@unsyiah.ac.id \\ ${ }^{2}$ Center for Livestock Breeding and Forage Animal Feed (BPTU-HPT) Indrapuri. Reukih Dayah, Indrapuri, Aceh Besar 23373, Aceh, Indonesia
}

Manuscript received: 6 October 2020. Revision accepted: 24 November 2020

\begin{abstract}
Melia J, Siregar TN, Alfahmi L, Husnurrizal, Saumar H, Mukhtar, Meutia N, Panjaitan B, Armansyah T. 2020. Short Communication: Relationship between interferon-tau level (IFN- $\tau$ ) and embryo mortality incident in Aceh cattle. Biodiversitas 21: 5758-5762. The purpose of this research is to determine the relationship between interferon-tau level (IFN- $\tau$ ) and the incidence of embryo mortality in Aceh cattle from the Province of Aceh, Indonesia. Data were obtained from four Aceh cattle, aged 3-5 years and body weight of $150-250 \mathrm{~kg}$. The cattle were clinically healthy, with at least two regular reproduction cycles, and a pregnant status after estrous synchronization and artificial insemination. This process was carried out on a 10-day interval using the intramuscular administration of prostaglandin F2 alpha (PGF2 $\alpha$ ) hormone, at a dose of $25 \mathrm{mg}$, with double injection pattern. The blood samples were collected from the jugular vein on day 14 to 18 post-insemination for the assessment of IFN- $\tau$ concentration, which was measured using the enzyme linked-immunoassay (ELISA) method and the bovine interferon ELISA kit (Cusabio Technology LLC AII, USA). In addition, the transrectal ultrasonography method was used to test the pregnancy and embryo mortality of the cattle on the $25^{\text {th }}$ day. The examination was repeated every 10 days until day 55. The IFN- $\tau$ concentrations of pregnant cows against those with embryo mortality on the $14^{\text {th }}, 15^{\text {th }}, 16^{\text {th }}, 17^{\text {th }}$, and $18^{\text {th }}$ day, were $12.066 \pm 8.222$ vs $17.853 \pm 11.126,12.983 \pm 3.491$ vs $20.503 \pm 3.858,12.193 \pm 4.535$ vs $16.458 \pm 8.065,10.143 \pm 5.370$ vs $17.604 \pm 1.888$, and $12.767 \pm 7.753$ vs $15.096 \pm 6.955 \mathrm{pg} / \mathrm{mL}$, respectively. Therefore, the embryo mortality in Aceh cattle is not related to IFN- $\tau$.
\end{abstract}

Keywords: Aceh cattle, IFN- $\tau$, embryo mortality

\section{INTRODUCTION}

Embryo mortality is defined as an interruption to the reproduction performance of cows which results in the death of the embryo before the $42^{\text {nd }}$ day of pregnancy (Efendi et al. 2015). This is divided into two categories, in accordance with the time of death, namely early embryo mortality (EEM), which occurs until the $27^{\text {th }}$ day, and late embryo mortality (LEM) between the $28^{\text {th }}$ to the $42^{\text {nd }}$ day) (Humblot 2001). Infection, environmental status, nutrition, management, and hormonal disorders generally cause this incident.

The success of pregnancy is influenced by embryo development, which is initiated from the blastocytes, followed by the hatch zone pellucida, and the trophoblast function, which produces components that prevent luteolytic and maintain pregnancy. There are four stages of embryo growth prior to implantation; these include proper development in the zona pellucida, hatching blastocytes, maternal recognition of pregnancy, and formation of the embryo outer membrane (Senger 2005). However, embryo death ensues when there is a failure in any one of these four stages.

Several studies have reported that early embryonic mortality was attributed to disturbances of signaling regulation between blastocyst and maternal endometrium or maternal recognition of pregnancy (MRP) (Raheem 2017). One of MRP in ruminant is interferon-tau (IFN- $\tau$ ) (Imakawa et al. 2017), also known as bovine interferon- $\tau$ (bIFN- $\tau$ ) in cattle (Basavaraja et al. 2017; Raheem 2017), which is produced during the first 14 days of pregnancy (Balhara et al. 2013), from initiation of blastocyst elongation (Imakawa et al. 2017) until 21 days of pregnancy (Hansen et al. 2017; Mishra and Sarkar, 2018). Implantation success is determined by the maternal recognition of pregnancy, due to the synthesis and secretion of interferon-tau (IFN- $\tau$ ) (Spencer et al. 2013). Furthermore, the synergistic mechanism of action between progesterone, IFN- $\tau$, and prostaglandins is needed for the maintenance of pregnancy in cows through a pre-implanted regulator in the endometrium (Dorniak and Spencer 2013).

Besides being used as a basis for early pregnancy diagnosis, the identification of IFN- $\tau$ in the blood has also been associated with premature embryo mortality. The injection of IFN- $\tau$ purification into the uterine lumen inhibits the luteolytic, thereby leading to early mortality of cow embryos (Martal et al. 1987; Matsuyama et al. 2012; Spencer and Bazer 2015). Furthermore, barriers and disturbances can cause corpus luteum regression and interferes in the development of chorioallantois placentas 
which results in embryo mortality due to the low IFN- $\tau$ levels (Wiltbank et al. 2016).

Interferon- $\tau$ is produced between the $12-19^{\text {th }}$ days of pregnancy, with the highest levels being seen on the 15 to 16th days. This is followed by a gradual decrease until the $19^{\text {th }}$ day or between the 14 and $21^{\text {st }}$ days, with the highest level seen on the $16^{\text {th }}$ day (Farin et al. 1980; Sheikh et al. 2018). IFN- $\tau$ is a pregnancy marker produced to influence the inhibition mechanism of luteolytic by the endometrium. It maintains the corpus luteum in an attempt to continuously produce progesterone, thereby having a significant effect on embryonic growth (Bazer et al. 2010). Approximately $10-15 \%$ of pregnancy failure, and consequently embryo mortality, in cows, is caused by the inadequate production of IFN- $\tau$ required to maintain the corpus luteum in the luteolytic phase (Spencer et al. 1995). This reinforces the need to acquire more adequate knowledge in the field of mortality detection specifically for the development of a diagnostic technique that pertains to the increase of cow productivity.

Lucy and Pooks (2012) reported that IFN- $\tau$ cannot be assayed directly in blood. On the contrary, Antoniazzi et al. (2012) stated that IFN- $\tau$ can be detected in the uterine veins of sheep on the $15^{\text {th }}$ day of pregnancy. Since the IFN- $\tau$ action occurs through the paracrine and endocrine mechanisms, it was assumed that IFN- $\tau$ could be detected in peripheral blood. In our preliminary study also proved that IFN- $\tau$ could be detected in blood serum of Aceh cows on $14^{\text {th }}$ day of pregnancy. Therefore, this study was conducted to determine the level of IFN- $\tau$ in the blood samples of Aceh cows with the intention of maintaining pregnancy and preventing early embryo mortality.

\section{MATERIALS AND METHODS}

\section{Materials}

A total of four cows between the ages of 3-5 years and body weight of $150-250 \mathrm{~kg}$, were artificially impregnated via insemination. Furthermore, they were characterized to be clinically healthy with normal reproductive organs and experienced at least two regular cycles. The cows were examined in accordance with the criteria of the Ministry of Agriculture Decree Number 2907/Kpts/OT.140/6/2011.

\section{Research procedure}

\section{Estrous synchronization and artificial insemination}

The double injection pattern with a 10-day interval was used on all female cows, with the prostaglandin (Lutalyse $^{\mathrm{TM}}$, Pharmacia \& Upjohn Company, Pfizer Inc.) injected intramuscularly at a dose of $25 \mathrm{mg}$. Also, estrus detection was performed in the morning (8:00) and afternoon (16:00) for 30 minutes, and determined by the presence of a red and swollen vulva, as well as transparent cervical mucus discharge, which indicated their readiness to mate (Sudarmaji et al. 2012). The artificial insemination was carried out 12 hours after the cows showed estrus behavior.

\section{Blood sampling}

Approximately $10 \mathrm{~mL}$ of blood samples were taken from the jugular vein from $14^{\text {th }}$ day to $18^{\text {th }}$ day, daily after insemination. The samples were further placed in a blood tube and left for several hours to allow for the separation of serum. The samples were then centrifugated at a speed of $3000 \mathrm{rpm}$ for 10 minutes. This preparation was transferred into the microtube and stored in the freezer at a temperature of $-20^{\circ} \mathrm{C}$.

\section{Measurement IFN- $\tau$ Concentration}

The serum was examined by the enzyme linkedimmunoassay (ELISA) method, using Bovine Interferon ELISA Kit (Cusabio Technology LLC AII, USA). Furthermore, all reagents, standard solutions, and samples were prepared and $100 \mu \mathrm{L}$ placed into each microplate well, which was subsequently incubated for 2 hours at $37^{\circ} \mathrm{C}$. In addition, the solution was removed from the well microplate with $100 \mu \mathrm{l}$ of Biotin-antibody (1x) added and incubated for 1 hour at $37^{\circ} \mathrm{C}$. These were all aspirated, with the process repeated twice and washed 3 times using a 200 $\mu \mathrm{L}$ wash buffer. Consecutively, $100 \mu \mathrm{l}$ of HRP-avidin (1x) was added to each well microplate, and incubated for 1 hour at $37^{\circ} \mathrm{C}$. It was further aspirated and washed 5 times, followed by the addition of $90 \mu \mathrm{L}$ TMB substrate, which was incubated for $15-30$ minutes at a temperature of $37^{\circ} \mathrm{C}$ in the absence of light. Finally, a $50 \mu \mathrm{L}$ stop solution was added to the well microplate, and read at $450 \mathrm{~nm}$ after 5 minutes.

\section{Pregnancy checking and diagnosis of embryo mortality}

Pregnancy examination was conducted using transrectal ultrasonography on the $25^{\text {th }}$ day after artificial insemination, and repeated every 10 days to the $55^{\text {th }}$ day, in accordance with Caudhary and Purohit (2012) instructions. In addition, transrectal ultrasonography was carried out using Mindray DP 10 Vet linear transrectal probe 50L60EAV (Shenzhen Mindray Bio-Medical Electronics Co., Ltd.). Cows are considered pregnant on the $25^{\text {th }}$ day, based on the presence of anechoic fluid, with visualization of the embryo and heart rate in the cornual located in the uterus. However, embryo mortality was diagnosed on the $35^{\text {th }}$ day which was characterized by the absence of embryonic visibility, positive signs of pregnancy, and the presence of degeneration. The data were analyzed descriptively.

\section{RESULTS AND DISCUSSION}

A total of four pregnant Aceh cows were used to carry out this experiment, which was examined for embryo mortality. The results showed that two $(50 \%)$ pregnancies survived until the 55th day, while the remaining cows experienced embryo mortality due to late embryonic mortality/LEM, on the $35^{\text {th }}$ and $45^{\text {th }}$ day, respectively. The total concentration of IFN- $\tau$ in LEM cows from days 14 to 18 were higher than pregnant cows as shown in Figure 1. The ultrasonography result showed the survival rate up to the $55^{\text {th }}$ day, as seen in Figure 2 and Figure 3 for LEM Aceh cattle. 

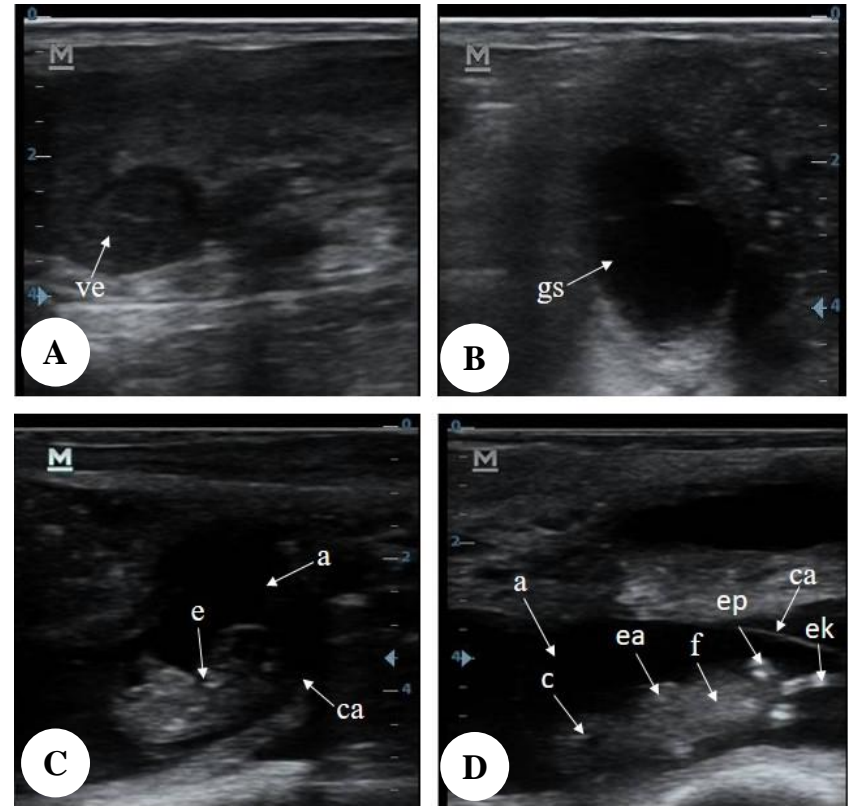

Figure 2. Image of uterus sonography in pregnant Aceh cattle Note: A. Uterus pregnant day 25, B. Uterus pregnant day 35, C. Uterus pregnant daily, D. Uterus pregnant day 55 (ve: embryonic vesicle, gs: Gestational sac, ea: anterior extremities, ep: posterior extremities, ek: tail; a: amnion, c: cranium e: embrio, f: fetus; bar $=0.5 \mathrm{~cm})$

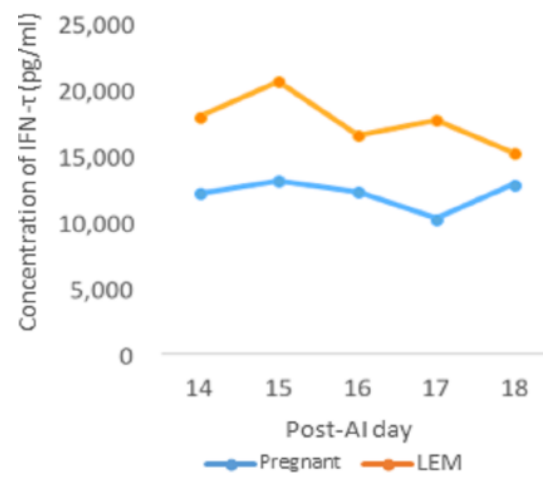

Figure 1. Interferon- $\tau$ concentration in pregnant cows and late embryonic mortality/LEM

The final IFN- $\tau$ secretions in pregnant and LEM cows achieved on the $15^{\text {th }}$ day were $12.983 \pm 3.491 \mathrm{pg} / \mathrm{mL}$ and $20.503 \pm 3.858 \mathrm{pg} / \mathrm{mL}$, respectively. The results differed from the report of Bazer et al. (2009), which concluded that the IFN- $\tau$ secretion climax occurred on the $16^{\text {th }}$ and $14^{\text {th }}$ day by $136.09 \mathrm{pg} / \mathrm{mL}$, and $82.70 \mathrm{pg} / \mathrm{mL}$ in LEM cow. Farin et al. (1980) reported on the occurrence of climax, which took place between $15-16^{\text {th }}$ day of pregnancy, with differences in time and concentration ensuing due to the variation in breeds and the number of cows. In this research, 16 breeds Karan fries were used to determine the differences in management (Bazer et al. 2009).

The concentration of IFN- $\tau$ was lower in pregnant cows compared to LEM, as shown in Figure 1. However, Bazer
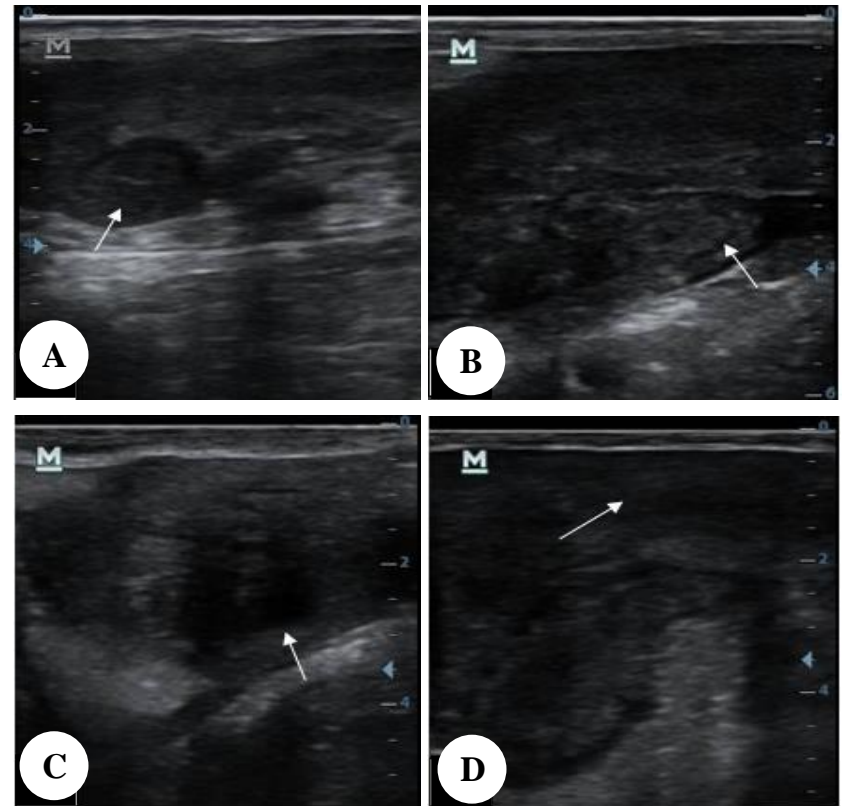

Figure 3. Image of uterus sonographic in Aceh cattle experiencing late embryonic mortality (LEM). Note: A. Pregnant uterus day 25, B. LEM 3day 35, C. LEM day 45, D. LEMday 55

et al. (2009) stated a reverse report. This variation is due to differences in the number of samples, with a possibility that the occurrence of LEM is not related to the level of IFN- $\tau$. The cause of embryo mortality was due to infection (endometritis), the environment, nutrition, management, and hormonal disorders (Prihatno et al. 2013). Also, longlasting endometritis leads to repeated breeding in cows and embryo mortality. This possibility is supported by research carried out by Rafika (2017) which stated that repeat breeding is identified by the presence of Escherichia coli, Pseudomonas sp., Klebsiella sp., and Enterobacter sp. in the uterus which has the potential to cause embryo mortality. A poor uterine environment after parturition facilitates the entry of microbes into the uterine lumen, which is characterized by pollution of the uterine environment, and subsequent mortality (Noakes et al. 2001).

According to previous studies, embryo mortality is caused by the low production of IFN- $\tau$ by the embryonic trophectoderm (Matsuyama et al. 2012). In addition, the concentration of $12.983 \mathrm{pg} / \mathrm{mL}$ on the $15^{\text {th }}$ day after artificial insemination, was able to maintain pregnancy till the $55^{\text {th }}$ day, therefore making it an MRP. This helps to maintain the productivity of progesterone by the corpus luteum which is known to affect embryo growth (Bazer et al. 2010). Despite the occurrence of MRP in LEM cows, embryo mortality occurred as a result of the low secretion of IFN- $\tau$ (Matsuyama et al. 2012). Its role was examined in embryo formation within the uterus, characterized by the regulation of complement genes present in the parent endometrium (Arosh et al. 2016). In addition, during early 
pregnancy, the embryo extends leading to the production of more progesterone (Bazer et al. 2009). These IFN- $\tau$ are produced by the paracrine embryo trophoblast tissue, which impedes the action of oxytocin receptors (OTRs) in the endometrial epithelium, thereby inhibiting the release of endometrial pulses in the form of prostaglandins (PGF2 $\alpha$ ) (Spencer et al. 2013). Consequently, there is also a marked increase in the production of endometrial lutein-protective mediators of prostaglandin (PGE2) and the interferon-tau show to play an important role in embryo extension and the continuity of pregnancy (Spencer et al. 2013; Arosh et al. 2016).

The findings in the present study differed from the previous study. Serrano-Pérez et al. (2019) reported that the expression of interferon-tau stimulated gene (ISG15) was higher in pregnant cows compared to the non-pregnant cows. Yaginuma et al. (2019) stated that the concentration of bIFN- $\tau$ expression of mRNA from ISG15) in pregnant cows (which have been determined to be repeat breeders) was significantly higher than the non-pregnant cows with the same repeat breeding patterns. Guo et al. (2020) also detected an increase of bIFN- $\tau$ concentration at days 14 post AI. Furthermore, Zhu et al. (2017) observed an increase of bIFN- $\tau$ concentration in pregnant cows compared to non-pregnant cows.

Figure 2 shows a description of uterine ultrasonography in Aceh cattle which indicates pregnancy, due to the presence of embryonic vesicles (Amrozi and Setiawan 2011). Furthermore, it shows an isoechoic to hyperechoic appearance, which surrounds the hypoechoic fluid, in contrast with the study conducted by Chaudary and Purohit (2012) and Sayuti et al. (2016). Cows are considered pregnant on the $25^{\text {th }}$ day after insemination based on the presence of anechoic fluid and adequate visualization of the embryo and heart rate in the cornual of the uterus. This research showed that pregnant cows showed embryonic vesicles due to the presence of various breeds. Also, the ultrasonography conducted on the $35^{\text {th }}$ day showed the presence of a gestational sac (a pregnancy bag filled with anechoic and amniotic fluid, with a chorioallantois hypoechoic as well as hyperechoic membrane), and an embryo on the $45^{\text {th }}$ day. Furthermore, the gestational sacs and fetuses were visible with hyperechoic colored heads, as well as extremities and tails on the $55^{\text {th }}$ post insemination day.

Figure $3 \mathrm{a}$ shows the embryonic vesicles of pregnant cows on the $35^{\text {th }}$ day, while Figure $3 b$ demonstrates the degenerated uterus and embryonic vesicles decay, indicated by hypoechoic to hyperechoic colors. Figure 3c shows the absorption of the dead embryo by the mother as the sonographic picture disappeared, despite the presence of the amniotic fluid with anechoic to hypoechoic coloration on the $45^{\text {th }}$ day. Figure $3 \mathrm{~d}$ shows the absorption of amniotic fluid by the body on the $55^{\text {th }}$ day, which is characterized by the uterine lumen shrinkage and endometrial thickening. In conclusion, embryo mortality in Aceh cattle was not shown to be related to IFN- $\tau$.

\section{ACKNOWLEDGEMENTS}

The authors are grateful to the Rector of Syiah Kuala University, Banda Aceh, Indonesia for the funds provided to carry out this research through the Professor Grant research scheme of the 2019 budget year.

\section{REFERENCES}

Amrozi, Setiawan B. 2011. Sinkronisasi estrus dan pengamatan ultrasonografi pemeriksaan kebuntingan dini pada domba garut (Ovis aries) sebagai standar penentuan umur kebuntingan. J Kedokteran Hewan, 5 (2): 73-77. [Indonesian]

Antoniazzi AQ, Latimer AM, Romero JJ, Niswender GD, Bazer FW, Nett TM, Hansen TR. 2012. Detection of interferon-tau in uterine vein blood using a highly sensitive and specific radioimmunoassay. Biol Reprod 87 (1): 183-188.

Arosh JA, Banu SK, McCracken JA, 2016. Novel concepts on the role of prostaglandins on luteal maintenance and maternal recognition and establishment of pregnancy in ruminants. J Dairy Sci 99 (7): 59265940 .

Balhara AK, Mohanty AK, Gupta M, Singh I. 2013. Early pregnancy diagnosis in bovines: Current status and future directions. Sci World J 2013: 958540. DOI: 10.1155/2013/958540.

Basavaraja R, Madusanka ST, Drum JN, Shrestha K, Farberov S, Wiltbank MC, Sartori R, Meidan R. 2019. Interferon-tau exerts direct prosurvival and antiapoptotic actions in luteinized bovine granulosa cells. Sci Rep 9: 14682. DOI: 10.1038/s41598-019-51152-6.

Bazer FW, Spencer TE, Johnson GA, Burghardt RC, Wu G. 2009. Comparative aspects of implantation. Reproduction 138 (2): 195-209.

Bazer FW, Wu G, Spencer TE, Johnson GA, Burghardt RC, Bayless K, 2010. Novel pathways for implantation and establishment and maintenance of pregnancy in mammals. Mol Hum Reprod 16 (3): 135-152.

Chaudary AK, Purohit GN. 2012. Ultrasonographic detection of early pregnancy loss in dairy cows. J Anim Sci Adv 2 (8): 706-710.

Dorniak P, Spencer TE, 2013. Biological roles of progesterone, prostaglandins, and interferon tau in endometrial function and conceptus elongation in ruminants. Anim Reprod 10 (3): 239-251.

Efendi M, Siregar TN, Hamdan H, Dasrul D, Thasmi CN, Daud R, Sayuti A, Panjaitan B. 2015. Angka kebuntingan sapi lokal setelah diinduksi dengan protokol ovsynch. J Med Vet 9 (2): 159-162. [Indonesian]

Farin CE, Imakawa K, Hansen TR, McDonell JJ, Murphy CN, Farin PW, Roberts RM. 1980. Expression of trophoblastic interferon genes in sheep and cattle. Biol Reprod 43 (2): 210-218.

Guo R, Chen F, Mei C, Dai Z, Yan L, Shi Z. 2020. Conception rate and reproductive hormone secretion in Holstein cows immunized against inhibin and subjected to the ovsynch protocol. Animals 10 (2): 1-10.

Hansen TR, Sinedino LDP, Spencer TE. 2017. Paracrine and endocrine actions of interferon tau (IFNT). Reproduction 154 (5): 45-59.

Humblot P. 2001. Use of pregnancy-specific proteins and progesterone assays to monitor pregnancy and determine the timing, frequencies and sources of embryonic mortality in ruminants. Theriogenology 56 (9): 1417-1433.

Imakawa K, Bai R, Nakamura K, Kusama K. 2017. Thirty years of interferon-tau research: Past, present and future perspective. A review article. Anim Sci J 88 (7): 927-936.

Lucy M, Poock S. 2012. Pregnancy determination by palpation and beyond. Proceedings Applied Reproductive Strategies in Beef Cattle December 3-4, Sioux Falls, SD.

Martal J, Charlier M, Charpigny G, Camous S, Chene N, Reinaud P, Sade S, Guillomot M. 1987. Interference of trophoblastin in ruminant embryonic mortality: A review. Livest Prod Sci 17: 193-210.

Matsuyama S, Kojima T, Kato S, Kimura K. 2012. Relationship between quantity of IFNT estimated by IFN-stimulated gene expression in peripheral blood mononuclear cells and bovine embryonic mortality after AI or ET. Reprod Biol Endocrinol 10 (21): 1-10.

Mishra SR, Sarkar M. 2018. Interferon stimulated genes (ISGs): Novel pregnancy-specific biomarker in buffaloes (Bubalus bubalis). J Immunol Sci 2 (2): 48-51.

Noakes D, Parkinson T, England G, Arthur G. 2001. Arthur's Veterinary Reproduction and Obstetrics. 8th ed. W.B. Saunders Ltd., USA. 
Prihatno SA, Kusumawati A, Karja NWK, Sumiarto B, 2013. Prevalensi dan faktor resiko kawin berulang pada sapi perah pada tingkat peternak. J Vet 14 (4): 452-461. [Indonesian]

Rafika I. 2017. Isolasi dan Identifikasi Bakteri Gram Negatif pada Uterus Sapi Aceh yang Mengalami Repeat Breeding. [Thesis]. Syiah Kuala University, Banda Aceh. [Indonesian]

Raheem KA. 2017. An insight into maternal recognition of pregnancy in mammalian species. J Saudi Soc Agric Sci 16 (1): 1-6.

Sayuti A, Melia J, Marpaung IK, Siregar TN, Syafruddin, Amiruddin, Panjaitan B. 2016. Diagnosis kebuntingan dini pada kambing kacang (Capra sp.) menggunakan ultrasonografi transkutaneus. J Kedokteran Hewan 10 (1): 63-67. [Indonesian]

Senger PL. 2005. Pathways to Pregnancy and Parturition. Washington State University Research \& Technology Park. $2^{\text {nd }}$ ed. Current Conception Inc., Washington.

Serrano-Pérez B, Rizos D, López-Helguera I, Molina E, Garcia-Ispierto I, López-Gatius F. 2019. Progesterone supplementation during the preimplantation period influences interferon-stimulated gene expression in lactating dairy cows. Ann Anim Sci 19 (3): 713-724.

Sheikh AA, Hooda OK, Kalyan A, Kamboj A, Mohammed S, Alhussein M, Reddi S, Shimray PG, Rautela A, Pandita S, Kapila S, De S, Dang AK. 2018. Interferon tau stimulated gene expression: A proxy to predict embryonic mortality in dairy cows. Theriogenology 120: 6167

Spencer TE, Bazer FW. 2015. Implantation and establishment of pregnancy in ruminants. Adv Anat Embryol Cell Biol 216: 105-135.
Spencer TE, Forde N, Dorniak P, Hansen TR, Romero JJ, Lonergan P. 2013. Conceptus-derived prostaglandins regulate gene expression in the endometrium prior to pregnancy recognition in ruminants. Reproduction 146 (4): 377-387.

Spencer TE, Ing NH, Ott TL, Mayes JS, Becker WC, Watson GH, Mirando MA, Brazer FW. 1995. Intrauterine injection of ovine interferon-tau alters oestrogen receptor and oxytocin receptor expression in the endometrium of cyclic ewes. J Mol Endocrinol 15 (2): 203-220

Sudarmaji S, Malik A, Gunawan A. 2007. Pengaruh penyuntikan prostaglandin terhadap persentase birahi dan angka kebuntingan sapi Bali dan PO di Kalimantan Selatan. Majalah Ilmiah Peternakan 10 (1): -. [Indonesian]

Wiltbank MC, Baez GM, Garcia-Guerra A, Toledo MZ, Monteiro M, Melo PL, Ochoa JC, Santos JE, Sartori R. 2016. Pivotal periods for pregnancy loss during the first trimester of gestation in lactating dairy cows. Theriogenology 86 (1): 239-253.

Yaginuma H, Funeshima N, Tanikawa N, Miyamura M, Tsuchiya H, Noguchi T, Iwata H, Kuwayama T, Shirasuna K, Hamano S. 2019. Improvement of fertility in repeat breeder dairy cattle by embryo transfer following artificial insemination: Possibility of interferon tau replenishment effect. J Reprod Dev 65 (3): 223-229.

Zhu Z, Li B, Wu Y, Wang X, Deng G. 2017. Interferon-t increases BoLAI for implantation during early pregnancy in dairy cows. Oncotarget 8 (56): 95095-9107. 